
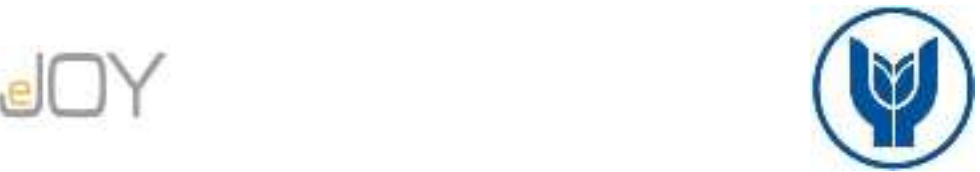

Dursun, G., Yeşilmen, Z. / Journal of Yasar University, 2021, 16/61, 434-454

\title{
Türkiye’de Yüksek Eğitim, Sağlık ve Ekonomik Büyüme Arasındaki Dinamik İlişkinin Analizi
}

\section{The Analysis of Dynamic Relationship between Higher Educational, Health and Economic Growth in Turkey}

Gülten DURSUN, Kocaeli Üniversitesi, Türkiye, dgulten@kocaeli.edu.tr

Orcid No:0000-003-2430-3412

Zeynep YEŞILLMEN, Kocaeli Üniversitesi, Türkiye, yesilmen23@gmail.com

Orcid No:0000-0003-0802-3592

Öz:Bu çalışmada Türkiye'de 1991-2018 dönemi için beşeri sermaye yatırımı olarak yükseköğretim, sağlık ve ekonomik büyüme arasındaki uzun vadeli ilişki Gregory-Hansen (GH) yapısal kırılmalı eşbütünleşme yaklaşımıyla incelenmiştir. Eşbütünleşme vektöründeki yapısal değişim altında değişkenler arasında eşbütünleşme ilişkisi tespit edildikten sonra model C/T için bulunan eşbütünleşme ilişkisi dikkate alınarak, uzun dönem katsayılarının elde edilmesinde Tam Değiştirilmiş EKK (FMOLS), Dinamik En Küçük Kareler (DOLS) ve Kanonik Eşbütünleşme Regresyonu (CCR) tahmincileri kullanılmıştır. Temel sonuçlarımız yükseköğretimin ekonomik büyüme üzerinde negatif bir etkiye sahip olduğunu göstermiştir. Bu sonuç teorik öngörülerle çelişmekle birlikte Türkiye'de genç işsiz sayısının artmaya devam etmesi, yükseköğretimin planlanmamış karakterini ortaya çıkarmıştır. Bu bulgu Türkiye ekonomisinin düşük beceri ve düşük üretkenlik faaliyetlerinde uzmanlaştı̆̆ının da bir ifadesidir. Dolayısıyla yükseköğretimin nitel yönlerinden ziyade niceliksel olarak genişlemesinin ekonomik büyümeye katkıda bulunmadı̆̆ bu çalışmanın önemli bir bulgusudur. Sağlıkla ilgili dikkate aldığımız vekil değiş̧en olarak doğumda yaşam beklentisinin ekonomik büyüme üzerindeki etkisi pozitif ve sabit sermaye yatırımlarının etkisinden daha büyüktür. Hacker ve Hatemi-J (2006) bootstrap nedensellik test

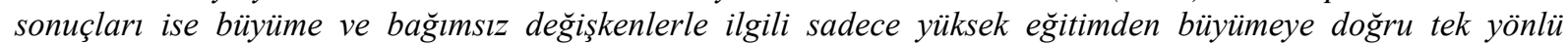
nedensellik ilişkisi tespit edilmiştir.

Anahtar Kelimeler: Yüksek Eğitim, Sağlık, Ekonomik Büyüme, Gregory-Hansen Eşbütünleşme Yaklaşımı

JEL Sinıflandirmasi:B23, I15, I23, J24, O47

Abstract: In this study, a long-term relationship between higher education as human capital investment, health and economic growth was investigated for the period 1991-2018 in Turkey through Gregory-Hansen (GH) cointegration approach with structural break. After determining the cointegration relationship between variables under the structural change in the cointegration vector and via taking the cointegration relationship found for model C/T into account, Fully Modified EKK (FMOLS), Dynamic Least Squares (DOLS) and Canonical Cointegration Regression (CCR) estimators were used. Our main results have shown that higher education has a negative impact on economic growth. Although these results are inconsistent with theoretical predictions, continuation of increase in the number of young unemployed people in Turkey revealed the unplanned character of higher education. This finding is also an expression which signifies that Turkey's economy is specialised in low skills and low productivity. Therefore, it is an important finding of this study that the expansion of higher education quantitatively rather than qualitatively does not contribute to economic growth. As the proxy variable that we considered regarding health, the effect of life expectancy at birth on economic growth is positive and greater than fixed capital investments. Hacker and Hatemi-J (2006) bootstrap causality test results related to growth and independent variables revealed a unidirectional causality relationship only from higher education towards growth.

Keywords: Higher Education, Health, Economic Growth, Gregory-Hansen Cointegration Approach

JEL Classification: B23, I15, I23, J24, O47

\section{Giriş}

Genel olarak eğitim ve özellikle yükseköğrenim, ekonomik büyüme ve sürdürülebilir kalkınmanın en önemli faktörlerinden biridir. Ekonomik büyümenin eğitimle ilişkisinin sağlam bir teorik çerçevesi olmasına rağmen (Romer, 1990a; Mankiw vd., 1992; Lucas, 1993; 
Barro ve Sala-i-Martin, 1995; Greiner vd., 2005), eğitim sisteminin farklı düzeyleri hakkında hala çok az ampirik kanıt bulunmaktadır (Dănăcică, 2011; Awel, 2013; Hamdan vd., 2020). Beşeri sermaye hipotezine göre, daha iyi eğitim ve iyileştirilmiş sağlık, daha yüksek ekonomik büyüme ve kalkınma için bir araçtır (Kim vd., 2017). Yükseköğretimin büyümeye doğrudan katkısı ne olursa olsun, eğitimli insan gücünün varlığı, kaynak sahiplerinin yeni firsatlara verdiği yanıtları hızlandırarak yeniliklerden kaynaklanan dengesizliklerin düzeltilmesini kolaylaştırmaktadır (Hoenack, 1993). Dolayısıyla eğitimli ve sağlıklı çalışan işgücü daha verimli hale gelirken, yeni teknolojilere uyum sağlayabilmekte ve daha fazla kazanç elde edebilmektedir. Mikro düzeydeki kanıtlar bireyin sağlık ve eğitim düzeyinin verimlilik ve ücret performansını belirlediğini göstermektedir (Harmon vd., 2003; Behrman ve Rosenzweig, 2004; Bleakley, 2007).

Beşeri sermaye kavramı, işgücü faktörü içerisine gömülü maddi olmayan kaynak seti olarak yorumlanabilir (Goldin, 2016). Bu kaynak seti içerisinde eğitim, deneyim ve sağlık hizmetleri yoluyla edinilen bilgi ve beceriler yer almaktadır (Schultz, 1961; Becker, 1962). Schultz (1963:43) her eğitim aşamasının işgücü verimliliğini arttırdığını, ancak daha yüksek aşamaların daha fazla kaynak gerektirdiğini ileri sürmektedir. Benzer şekilde Yu vd. (2014:463) yükseköğretimi sosyoekonomik sistemin bir parçası olarak ele almakta, fon ve beşeri sermaye girdileri açısından sosyal kaynakların desteği olmadan sistemin etkili ve düzgün bir şekilde çalışmadığını vurgulamaktadır.

Ekonomik büyüme ve işgücünün sağlığı arasındaki bağlantının erken kabulüne rağmen, beşeri sermaye yatırımlarının getirisine ilişkin ampirik literatürün büyük bir bölümü eğitimin verimlilik üzerine olan etkisine odaklanmıştır. Büyüme literatüründe, beşeri sermayenin bir bileşeni olarak sağlık genellikle yaşam beklentisi ile özdeşleşmektedir. İçsel bir büyüme modeli çalışmasında Ehrlich ve Lui (1991), yaşam beklentisindeki bir artışın, gelecek nesillere beşeri sermaye yatırımını motive etmek suretiyle büyümeyi teşvik edebileceğini savunmaktadır. Benzer şekilde Barro (1997), hem eğitimsel kazanımın hem de yaşam beklentisinin, kişi başına reel GSYİH büyüme oranı ile pozitif ilişkili olduğunu göstermektedir. Böylece ekonomik gelişme nüfusun kazandığı beceri düzeyi ve sermaye birikimine bağlıdır. Sermaye birikimi ise yetişkin sağlığından da etkilenen tasarruf oranına bağlı olacaktır (Bhargava vd., 2001). Sağlığın iyileştirilmesi bir çok farklı yoldan ekonomik büyüme artış hızını etkilemektedir (Bloom vd., 2018). Daha iyi sağlık, işgücü piyasalarına katılımı ve işgücü verimliliğini artırmakta, yaşam beklentisindeki artışlar inovasyon ve fiziksel sermaye yatırımını teşvik etmekte ve özellikle kadınların sağlık durumlarının iyileştirilmesi doğurganlığı azaltarak sürdürülebilir büyümeye geçişe katkı sağlamaktadır. 
Beşeri sermayenin bir ülkenin ekonomik büyümesine katkısını ölçmeye yönelik çabalar Denison ve Poullier (1967)'in büyüme muhasebesi uygulamas ${ }^{1}$ ile başlasa da Romer (1986, 1990b) ve Lucas (1988) öncülüğünde gelişen endojen büyüme teorileriyle kavramsallaştırılmıştır. Ancak beşeri sermayenin eğitim ve sağlık gibi bileşenleri büyüme analizlerine dahil edilmekle birlikte, endojen büyüme teorileri bu bileşenler arasındaki nedensel ilişkileri açıklamamaktadır (Gemmell, 1995). Lucas (1988), beşeri sermaye oluşumunun büyüme ve kalkınma için önemini vurgulasa da büyüme modellerinde paradoksal olarak büyümenin kaynağı olan beşeri sermaye oluşumunun insanlarda tam anlamıyla somutlaştırıldığı göz ardı edilmektedir. Oysa insanlar ancak canlı ve sağlıklı olduklarında etkili bir beşeri sermaye oluşabilir. Dolayısıyla nüfusun sağlık durumundaki değişimin büyümeyi ve toplumsal refahı nasıl etkilediği, beşeri sermaye oluşumunun daha yakından incelenmesini gerektirmektedir (Van Zon ve Muyksen, 2001).

Çalışmanın temel amacı üç yönlüdür. İlk olarak, Türkiye'de beşeri sermaye ve ekonomik büyüme arasındaki uzun dönemli dinamik ilişkinin doğası incelenmektedir. İkinci olarak, bu çalışmada beşeri sermayenin vekil değişkeninin seçimi literatürde sıklıkla kullanılan eğitim harcaması, eğitim yılı ve kayıt sayısını kullanan çoğu çalışmadan farklıdır. Beşeri sermayenin yenilik (inovasyon) süreci ile yakından ilişkili olması (Mariz-Peréz vd., 2012), entelektüel sermaye çerçevesi içerisinde beşeri sermaye göstergesi açısından "yetişkin üniversite düzeyi”nin önemli bir rehber olacağı kanaatindeyiz. Böylece çalışmamızın temel katkısının Türkiye'nin insan kaynakları düzeyi ile yenilik kapasitesi arasındaki bağlantının ekonomik büyümeye yansıyıp yansımadığını test edebilmiş olacağız. Özellikle daha eğitimli işgücünün yeni teknolojileri daha hızlı benimseyebileceğini vurgulayan Nelson ve Phelps (1966)'in çalışmasının Türkiye için geçerliliği, yüksek eğitimin analize dahil edilmesi yoluyla test edilebilecektir.

Üçüncü olarak değişkenler arasındaki nedensellik ilişkileri hakkında daha fazla bilgi edinmek için bootstrap temelli Hacker-Hatemi-J (2006) nedensellik testi uygulanmaktadır. Beşeri sermaye-büyüme ilişkilerinin incelenmesine yönelik teorik çıkarımların nedensel etkileri ölçmemesi analitik bir endişe kaynağıdır. Yaygın görüş hızlı büyüyen ülkelerin eğitime yapılabilecek daha fazla kaynağa sahip olmasıdır. Ampirik araştırmamızın ilk bulguları, eğitimin uzun vadede ekonomik büyümeye negatif, yaşam beklentisinin ise büyümeye pozitif ve anlamlı katkıda bulunduğu yönündedir. Nedensellik ilişkisine yönelik bulgularımız ise sadece eğitimden büyümeye doğru tek yönlüdür.

${ }^{1}$ Denison ve Poullier (1967) toplam faktör girdileri ile olarak girdi ve çıtı arasında ayrım yaparak zaman içinde ekonomik büyümenin analizini yapmaktadır. Emek, sermaye ve toprak gibi girdilere ilişkin klasik yaklaşımı takip ederken, aynı zamanda işgücünün kalitesindeki değişim, işgücünün formal eğitimindeki değişikliklerdir. 
$\mathrm{Bu}$ çalışma beş bölümden oluşmaktadır. Girişten sonraki ikinci bölümde beşeri sermaye ve ekonomik büyümeye ilişkin literatüre yer verilmiştir. Üçüncü bölümde metodoloji ve veri tanıtılarak, analiz sonuçları dördüncü bölümde tartışılmış ve beşinci bölüm sonuçla tamamlanmıştır.

\section{Literatür Taraması}

Ekonomik büyümenin en önemli bileşenlerinden birinin beşeri sermaye olduğunu ortaya koyan geniş bir literatür bulunmaktadır. Barro (1996), sağlıkta yaşanan bir artışın, büyümeye doğrudan etkisinin yanında, eğitime olan talebi de arttırarak, üretkenlik üzerinde dolaylı yoldan olumlu etkisi olduğunu ileri sürmektedir. Eğitim, bilgi ve beceri biriktirerek, işgücü verimlilik ve üretkenlik artışlarını ve dolayısıyla ekonomik büyümeyi yönlendirecek inovasyon kaynağı olarak görülmektedir (Mariana, 2015; Hanushek, 2016). Aghion ve Howitt (1992)'e göre nitelikli işgücü tahsis etmeyen bir ekonomi hiçbir yenilik yaşayamayacağından dolayı büyüyemeyecektir. Ayrıca ekonomik büyüme, ülkenin bilgi sermayesiyle de büyük ölçüde ilintili olduğundan, eğitim düzeyindeki gelişmeler işgücü verimliliğini etkilerken bilgi sermayesini de arttırarak ekonomik büyümeyi pozitif yönde etkilemektedir (Mercan ve Sezer, 2014; Hanushek, 2016).

Beşeri sermaye ve ekonomik büyüme ilişkisini araştıran panel veya tek ülke üzerine birçok çalışma bulunmaktadır. Nitelikli işgücü göz önüne alınarak yükseköğretim, sağlığı temsilen doğumda yaşam beklentisi ile ekonomik büyüme ilişkisi üzerine yapılan panel ampirik çalışmalardan Li ve Liang (2010) ve Ogundari ve Awosuke (2018) yaşam beklentisi ve farklı eğitim değişkenleri kullanarak yaptıkları analiz sonucunda beşeri sermaye ve kişi başı GSYİH arasında uzun dönemli pozitif ilişki tespit etmişlerdir. Her iki çalışmada da sağlığın ekonomik büyümeye etkisinin göreceli olarak eğitimden daha büyük olduğu sonucuna ulaşmışlardır. Siddique vd. (2018) orta gelirli 76 ülke üzerine yaptıkları eşbütünleşme analiziyle yaşam beklentisinin büyümeyi pozitif etkilediğini, orta ve yüksekokul eğitiminin ise büyümeyi arttırmadığı sonucuna ulaşmıştır. Siddique vd.'lerinin çalışmalarını destekleyecek şekilde Neycheva (2019), 11 AB ülkesinde eğitimli işgücünün artan stokunun kişi başına GSYİH üzerinde olumlu bir etki yaratmadığını, Bowen ve Qian (2017) ise ABD’nin 50 eyaletinde yükseköğretim eğitim harcamaları ile kişi başı GSYİH arasında nedensellik ilişkisi olmadığını ortaya koymuştur.

Tek ülkeli çalışmalardan, Katırcıoğlu (2009) Kuzey Kıbrıs, Mariana (2015) ve Dănăcică vd. (2010) Romanya için yükseköğretimdeki öğrenci sayısını kullanarak eşbütünleşme ve nedensellik analizi yapmışlardır. Çalışmalarda yükseköğretim ve büyüme arasında uzun 
dönemli pozitif bir ilişki Kuzey Kıbrıs’ta yükseköğretimden büyümeye doğru, Romanya'da büyümeden yükseköğretime doğru tek yönlü nedensellik ilişkisi tespit edilmiştir. MarquezRamos ve Mourelle (2019) İspanya'da 1971-2013 yıllarında ortaokul ve yüksekokul eğitimi, eğitimli aktif nüfus oranı, eğitim harcamaları ve GSYİH arasında pozitif korelasyon tespit ederken, Hamdan vd. (2020) Suudi Arabistan'da yükseköğretime yapılan yatırımlar ve GSYİH arasında nedensellik ilişkisi bulamamıştır. Aka ve Dumont (2008), ABD için yaptığı analizde doğumda ortalama yaşam süresinden ekonomik büyümeye doğru tek yönlü nedensellik tespit ederken, Khan ve Laila (2019) Pakistan'da yaşam beklentisi ve ekonomik büyüme arasında bir ilişki olmadığı sonucuna ulaşmıştır.

Türkiye'de sağlığı temsilen doğumda yaşam beklentisi kullanılarak yapılan çalışmalardan Ak (2012), sağlık ile ekonomik büyüme arasında uzun dönemli pozitif ilişki, Taban (2006), çift yönlü nedensellik ilişkisi tespit etmiştir. Türkiye'nin de dahil edildiği 25 OECD ülkesi ile panel veri analizi yapan Yardımcıŏglu (2012)'nun çalışmasında değişkenler arasında uzun dönemli pozitif ve çift yönlü nedensellik ilişkisi olduğu sonucuna ulaşılmıştır.

Beşeri sermayeyi temsilen yükseköğretimin dikkate alındığı çalışmalardan; Şimşek ve Kadılar (2010) ve Ay ve Yardımcı (2008) yükseköğretime kayıt sayısını kullanarak yaptıkları eşbütünleşme analizi sonucunda büyüme ile arasında uzun dönemli pozitif bir ilişki, Şimşek ve Kadılar (2010) değişkenler arasında çift yönlü nedensellik ilişkisi tespit etmiştir. Topallı (2015), yaptığı eşbütünleşme ve nedensellik analizi ile yükseköğretimden diploma alanların sayısı ve kişi başı GSYİH arasında eşbütünleşme ilişkisi ve büyümeden yükseköğretime doğru tek yönlü nedensellik tespit etmiştir. Aynı zamanda Abdioğlu ve Albayrak (2018) GSYİH değişkeninin yanı sıra sektörel bazda GSYİH da dikkate alınarak yaptıkları çalışmayla hem sektörel bazda hem de GSYİH ile yükseköğretim mezun sayısı arasında uzun dönemli pozitif ilişki tespit etmiştir.

Türkiye'de yükseköğretimin ekonomik büyümeyi pozitif etkilediği ve/veya büyüme ile arasında nedensellik ilişkisi olduğunu gösteren literatürün aksine, Erdoğan ve Yıldırım (2009), 1983-2005 yılları arasında yüksekokullaşma oranının uzun dönemde ekonomik büyümeyi negatif etkilediği sonucuna ulaşmıştır. Ayrıca Erdem ve Tugcu (2012), 1960-2007 yılları için yaptıkları çalışmayla uzun dönemde yükseköğretimin işsizlik oranını arttırdığını ve aralarında çift yönlü nedensellik ilişkisi olduğunu ortaya koymuştur. Kim vd. (2017), Türkiye'nin de dahil edildiği gelişmiş ve gelişmekte olan 50 ülke grubunda yükseköğretim brüt kayıt oranı ve sağlık değişkenlerinin ekonomik büyümeye etkisini araştırmıştır. Çalışmalarının sonucunda sağlık ve eğitimin ortalama olarak geliri arttırdığını fakat ülkeler arasında büyük farklılıklar olduğunu; ekonomik kalkınmanın ilk aşamalarında sağlığın gelir 
üzerine etkisinin daha yüksek; ekonomik kalkınmanın sonraki aşamalarında olan ülkelerde ise eğitimin gelir üzerindeki etkisinin çok daha fazla olduğunu göstermiştir. Hanushek (2016)'e göre gelişmiş bilgi sermayesi yokluğunda yükseköğretim büyümeye sürekli katk1 sağlamayabilir. Ülkelerin bilgi sermayesi, büyüme oranlarındaki farklılıkların çoğunu açıklasa da bilişsel becerileri arttırmadan daha fazla eğitim yılı eklemek büyüme üzerinde çok az sistematik etkiye sahiptir.

\section{Model, Veri ve Yöntem}

Solow (1956) ve Swan (1956) tarafından çerçevesi çizilen ekzojen büyüme modeli, ekonomik büyümeyi analiz etmek için yararlı bir başlangıç noktası sunmakla birlikte, beşeri sermayenin rolü ihmal edilmiştir. Solow'un çalışmaları daha sonra Mankiw, Romer ve Weil (1992) (MRW) tarafindan beşeri sermaye (eğitim) teknolojinin Harrod-nötr olarak tanımlandığı Cobb-Douglas üretim fonksiyonuna ayrı bir şekilde dahil edilerek Solow modeli genişletilmiştir. Bununla birlikte sağlığın da beşeri sermayenin önemli bir bileşeni olarak kabul edilmesiyle bu alandaki çalışmalar hızla artmaya başlamıştır (örneğin bkz. Van Zon ve Muysken, 2001).

$\mathrm{Bu}$ çalışmada eğitim ve sağlığın ekonomik büyüme üzerindeki etkisi Genişletilmiş Solow Modeli çerçevesinde incelenmektedir. Grossman (1972) ve Bloom vd. (2004), bir kişinin bilgi veya bilgi stokunun piyasa ve piyasa dışı verimliliğini etkilediğini, sağlık stokunun ise parasal kazanç elde etmek ve emtia üretmek için harcayabileceği toplam zamanı belirlediğini ileri sürmektedir. Lucas (1988)'a göre ekonomik ajanlar iki değişken üzerinde kontrol sahibidir: tüketim seviyesi ve beceri edinmeye ayrilan süre. Tüketim seviyesi fiziksel sermaye birikimi seviyesini belirlerken, işe ayrılan zaman veya becerilerin kazanılması, ekonomik ajanların gelecekteki verimliliğini belirlemektedir.

Model (1)'de beşeri sermayenin çıktı üzerindeki etkisi üssel formda ifade edilmiştir. Beşeri sermaye, sağlık $(h)$ ve yüksek eğitim $(u)$ olarak ifade edilmektedir. $(k)$ ise fiziksel sermayeyi temsil etmektedir. Bu fonksiyonel formun en önemli avantajı genellikle mikro çalışmalarda tahmin edilen ilişkilerle uyumlu olan günlük ücretlerin eğitim ve sağlık statüsüne bağlı olmasıdır (Bloom vd., 2004). Böylece, kişi başına/işçi üretim fonksiyonu Cobb-Douglas formunda şu şekilde yazılır:

$Y=A k^{\alpha} e^{\varphi h+\delta u+\mu_{t}}$

Denklem (1) doğal logaritmik formda yeniden yazıldığında Denklem (2) elde edilir:

$\ln y=\ln A+\alpha \ln k+\varphi h+\delta u+\mu_{t}$ 
Burada A, ekonomideki teknolojik ilerlemenin (Toplam Faktör Verimliliği-TFV) bir ölçüsüdür. Teknoloji işgücü ve sermaye ile açıklanamayan çıktı büyümesini açıklayan bir değişkendir. Adu (2013) ve Boachi (2017)'de olduğu gibi endojen büyüme literatürü takip edilerek, teknolojinin ekonomi boyunca geliştiğini varsayıyoruz.

Bağımlı değişken olarak kişi başına reel GSYİH'nin alındığı ampirik eğitim-sağlıkbüyüme modeli Denklem (3) de olduğu gibidir:

$\ln y_{t}=\beta_{0}+\alpha \ln k_{t}+\varphi \operatorname{lnh} h_{t}+\delta u_{t}+\mu_{t}$

Burada $\alpha, \varphi, \delta$, Denklem (1)'de daha önce tanımlanan değişkenlerle ilgili olarak tahmin edilen parametrelerdir . $t$, zamanı, $\beta_{0}$, sabit terimi, $\mu_{t}$ modelin hata terimini temsil etmektedir.

\subsection{Veri}

Bu çalışmadaki değişkenler, 1991-2018 dönemi için 28 yıllık gözlemi içeren kişi başına GSYİH, sabit sermaye oluşumunun GSYİH içindeki payı, doğumda yaşam beklentisi ve yüksek eğitimdir (Bkz. Tablo 1). Kişi başına GSYİH (satın alma gücü paritesine (SGP) göre 2017 yılı sabit fiyatlarla ABD doları) ekonomik büyümenin (y) bir ölçüsü olarak kullanılırken, doğumda beklenen yaşam süresi (yıl) sağlık için vekil değişken olarak kullanılmaktadır $(h)$.

Farklı sağlı ölçütleri mevcut olmakla birlikte, ülkede insanların morbidite veya engellilik düzeyini göstermemesine rağmen, sağlık durumu için dikkate aldığımız doğumda yaşam beklentisi sağlıklı bir nüfusun göstergesidir (Boachie, 2017). Eğitime yapılan yatırım, aynı zamanda bebek ölüm oranı, anne ölüm oranı, yaşam beklentisi gibi sağlığı etkileyen sonuçlar üretirken, ekonomik büyüme üzerinde çarpan etkisi yaratmaktadır (Umar, 2017). Diğer yandan Carrin (1984) yaşam beklentisinin eğitimin de bir göstergesi olabileceğini ve ekonomik büyüme üzerindeki etkisinin sağlıktan çok eğitim bilgisi sağlayabileceğini belirtmiştir. Bu çalışmada Kim vd. (2017) takip edilerek yaşam beklentisi değişkeni, hem bebek ölüm oranı hem de morbiditenin çıktısı olarak dikkate alınmıştır.

Eğitim için 25-64 yaş grubundaki nüfusun tamamladığı üniversite eğitim seviyesi tarafından tanımlanan yetişkin eğitim düzeyi alınmıştır. Bu gösterge aynı yaştaki nüfusun yüzdesi olarak ölçülmektedir $(u)$. Kim vd. (2017) birçok yüksek ve orta gelirli ülkede ilköğretim kayıt düzeylerinin yüksek olması nedeniyle eğitim harcama önceliğinin ilköğretime yönelik olmadığını, tam tersine ilköğretim kayıt oranlarının daha düşük olduğu düşük gelirli ülkelerde, ilköğretime daha fazla öncelik verilebileceğini ileri sürmektedir ${ }^{2}$.

\footnotetext{
${ }^{2}$ Beşeri sermayenin büyüme üzerindeki etkisinin incelenmesinde kayıt oranlarının (okullaşma) vekil değişken olarak kullanılması yaygındır (örneğin bkz. Barro, 1991; Mankiw vd., 1992; Bils ve Klenow, 2000; Ranis vd., 2000). Ancak Hanushek ve Woessmann (2010) ülkeler aras1 karşılaştırmalarda farklı ülkelerdeki okulların tüm ülkelerde aynı miktarda eğitim verdiğinin varsayılması nedeniyle büyük zorluklar içerdiğini, eğitimin her ülkede aynı bilişsel becerileri üretemediğini belirtmektedir. Böylece yükseköğretimin beşeri sermayenin ölçüsü
} 
Eğitimin kalitesinin artması, ekonomik büyüme açısından eğitimin açıklayıcı gücünü artırmaktadır (Hanushek ve Wößmann, 2007). Bu çalışmada kullanılan yüksek eğitim vekil değişkeni, diğer ölçütlerin büyümeye katkısını yadsımamakla birlikte bir inovasyon kaynağı olarak beşeri sermayenin bir bileşeni olarak yararlı bir değişkendir.

Kişi başına GSYİH ve sabit sermaye yatırım verileri Dünya Bankası, Dünya Kalkınma Göstergeleri veri tabanından, yükseköğretim ve sağlık verileri OECD veri tabanı eğitim istatistiklerinden elde edilmiştir. Tüm değişkenlerin doğal logaritması alınmıştır.

Tablo 1. Analizde Kullanılan Değişkenler ve Veri Kaynakları

\begin{tabular}{|c|c|c|c|}
\hline Değişken & Tanım & Gözlem Aralı̆̆ & Veri Kaynă̆ \\
\hline $\ln y$ & $\begin{array}{l}\text { Kişi başına GSYIH (2017 yılı sabit } \\
\text { \$ fiyatlartyla, PPP) }\end{array}$ & $1991-2018$ & Dünya Bankası \\
\hline $\operatorname{lnk}$ & $\begin{array}{l}\text { Sabit sermaye yatırımlarının } \\
\text { GSYIH içindeki payı (\%) }\end{array}$ & $1991-2018$ & Dünya Bankast \\
\hline $\ln u$ & $\begin{array}{l}\text { 25-64 yaş grubu, yetiş̧kin eğitim } \\
\text { düzeyi, üniversite (\%) }\end{array}$ & $1991-2018$ & $O E C D$ \\
\hline $\operatorname{lnh}$ & Doğumda yaşam beklentisi (yul) & $1991-2018$ & $O E C D$ \\
\hline
\end{tabular}

Tablo 2'de tanımlayıcı istatistikler görülmektedir. Tüm değişkenler için Jarque - Bera test istatistiği olasılık değeri (p) 0.05 kritik değerinden büyük olduğu için hata terimleri normal dağılmaktadır.

Tablo 2. Tanımlayıcı İstatistikler

\begin{tabular}{|c|l|l|l|l|l|}
\hline Değişkenler & Ortalama & $\begin{array}{l}\text { Standart } \\
\text { Sapma }\end{array}$ & Min. & Max. & Jarque-Bera \\
\hline $\ln y$ & 9.80 & 0.25 & 9.44 & 10.25 & $2.15(0.341)$ \\
\hline $\ln k$ & 3.22 & 0.13 & 2.89 & 3.40 & $2.21(0.330)$ \\
\hline $\ln u$ & 2.35 & 0.39 & 1.56 & 3.03 & $0.86(0.649)$ \\
\hline $\ln h$ & 4.28 & 0.05 & 4.21 & 4.36 & $1.49(0.474)$ \\
\hline
\end{tabular}

Not: Parantez içindeki değerler p-olasılık değerlerini göstermektedir.

\subsection{Yapısal Kırılmalı Birim Kök Testleri}

\subsubsection{Zivot-Andrews (1992) Yapısal Kırılmalı Birim Kök Testi}

Zivot ve Andrews (1992), Perron'un birim kök analizinde yapısal kırılmanın ekzojen olduğu varsayımını sorgulayarak test istatistiklerini endojen olarak ele almaktadırlar. Üç model içinde yokluk hipotezi Denklem 4'te gösterilmektedir.

$y_{t}=\mu+y_{t-1}+e_{t}$

Alternatif hipotezin $\left(y_{t}\right)$, zamanın bilinmeyen bir noktasında trendde oluşacak tek seferlik bir kırılma ile trend-durağan sürecin temsil edileceği varsayılmaktadır. Buradaki amaç, trend- 
durağan alternatife en fazla etkiyi veren kırılmayı tahmin edebilmektir. Birim kökü test edebilmek için üç farklı model kurulabilmektedir. Model A; sabitte kırılma, model B; trendde kırılma; model C; hem sabitte hem de trendde kırılmayı temsil etmektedir (Zivot ve Andrews, 1992: 254).

Model A: $y_{t}=\hat{\mu}^{A}+\hat{\theta}^{A} D U_{t}(\hat{\lambda})+\hat{\beta}^{A} t+\hat{\alpha}^{A} y_{t-1}+\sum_{j=1}^{k} \hat{c}_{j}^{A} \Delta y_{t-j}+\hat{e}_{t}$

Model B: $y_{t}=\hat{\mu}^{B}+\hat{\beta}^{B} t+\hat{\gamma}^{B} D T_{t}^{*}(\hat{\lambda})+\hat{\alpha}^{B} y_{t-1}+\sum_{j=1}^{k} \hat{c}_{j}^{B} \Delta y_{t-j}+\hat{e}_{t}$

Model C: $y_{t}=\hat{\mu}^{C}+\hat{\theta}^{C} D U_{t}(\hat{\lambda})+\hat{\beta}^{C} t+\hat{\gamma}^{C} D T_{t}^{*}(\hat{\lambda})+\hat{\alpha}^{C} y_{t-1}+\sum_{j=1}^{k} \hat{c}_{j}^{C} \Delta y_{t-j}+\hat{e}_{t}$

t istatistiğinin en küçük olduğu tarih kırılma noktası olarak belirlenmektedir. Hesaplanan değer Zivot-Andrews kritik değerinden büyük olduğunda "birim kök vardır” boş hipotezi reddedilmektedir.

\subsubsection{Lee-Strazicich (2003) Yapısal Kırılmalı Birim Kök Testi}

Lee ve Strazicich (2003) testinin temel mantığı LM prensibine göre hareket etmesi, iki kırılma içermesi ve kırılma zamanını içsel olarak belirlenmesidir. LM prensibine göre iki kırılmalı birim kök regresyonu Denklem 8'deki gibidir (Lee ve Strazicich, 2003: 1083):

$\Delta y_{t}=\delta \Delta Z_{t}+\varnothing S_{t-1}+u_{t}$

Verilerin model A için, $Z_{t}=\left[1, t, D_{1 t}, D_{2 t}\right]^{\prime}$ şeklinde, model $\mathrm{C}$ için, $Z_{t}=$ $\left[1, t, D_{1 t}, D_{2 t}, D T_{1 t}, D T_{2 t}\right]^{\prime}$, şeklinde oluşturulduğu varsayılmaktadır. Analizde boş hipotez, $\emptyset=0$ “birim kök vardır” şeklindedir.

\subsection{Gregory-Hansen (1996) Kalıntı Temelli Eşbütünleşme Testi}

Geleneksel testlerde, eşbütünleştirici vektörün alternatif hipotez altında zamanla değişmeyeceği varsayılmaktadır. Gregory ve Hansen (1996), bundan dolayı eşbütünleşme için standart testlerin uygun olmadığını savunmaktadırlar. Gregory-Hansen (bundan sonra GH) testi bilinmeyen bir zamanda tek bir yapısal kırılmalı eşbütünleşme alternatif hipotezine karş1 “eşbütünleşme yoktur” boş hipotezini sınamaktadır. Alternatif hipotez altında yapısal değişimin zamanlaması içsel olarak tahmin edilmektedir. Gregory ve Hansen, eşbütünleşme vektörünün parametrelerindeki değişiklikleri barındıran üç alternatif model önermektedir. Model 1; sabitte kırılma (C), Model 2; sabitte ve trendde kırılma (C/T); Model 3; rejim değişmesini $(\mathrm{C} / \mathrm{S})$ temsil etmektedir.

Model 1: $y_{1 t}=\mu_{1}+\mu_{2} \varphi_{t \tau}+\alpha^{T} y_{2 t}+e_{t}, \quad t=1, \ldots, n$.
Model 2: $y_{1 t}=\mu_{1}+\mu_{2} \varphi_{t \tau}+\beta t+\alpha^{T} y_{2 t}+e_{t}, \quad t=1, \ldots, n$.
Model 3: $y_{1 t}=\mu_{1}+\mu_{2} \varphi_{t \tau}+\alpha_{1}^{T} y_{2 t}+\alpha_{2}^{T} y_{2 t} \varphi_{t \tau}+e_{t}, \quad t=1, \ldots, n$. 
Sabitte kırılma modelinde $\mu_{1}$, kırılma öncesindeki sabiti, $\mu_{2}$ kırılma sırasında sabitteki değişimi temsil etmektedir. Olası bir yapısal değişiklik, eğim vektörünün kaymasına olanak sağlamaktadır. $\mathrm{Bu}$ denge ilişkisinin dem dönmesine hem de paralel değişimine neden olmaktadır. Bu durum da rejim değişmesi olarak adlandırılmaktadır (Gregory ve Hansen, 1996: 103). Bu durumda $\mu_{1}$ ve $\mu_{2}$ sabitte kırılma modelindeki gibidir. $\alpha_{1}$ rejim değişiminden önce eşbütünleşme eğim katsayılarını, $\alpha_{2}$ eğim katsayılarındaki değişimi ifade etmektedir.

\subsection{Hatemi-J (2008) Eşbütünleşme Testi}

GH eşbütünleşme testinde tek kırılmaya izin verilirken, Hatemi-J (HJ) (2008)'nin geliştirdiği eşbütünleşme testinde iki kırılmaya izin verilmektedir. İki yapısal kırılmanın hem sabitte hem de rejimde (eğimde) değişimi göz önüne alınarak model Denklem 12'deki gibi genişletilmiştir.

$Y_{t}=\alpha_{0}+\alpha_{1} D_{1 t}+\alpha_{2} D_{2 t}+\beta_{0}^{\prime} X_{t}+\beta_{1}^{\prime} D_{1 t} x_{t}+\beta_{2}^{\prime} D_{2 t} x_{t}+u_{t}$

Denklem 12'de $y_{t}$, bağımlı değişken, $x_{t}$, bağımsız değişkenlerin vektörü, $\beta$, eğimlerin vektörü, $\mathrm{t}$ ise zaman göstergesidir. Burada $D_{1 t}$ ve $D_{2 t}$ şu şekilde tanımlanmış kukla değişkenlerdir:

$D_{1 t}=\left\{\begin{array}{l}0 \text { if } t \leq\left[n \tau_{1}\right] \\ 1 \text { if } t>\left[n \tau_{1}\right]\end{array}\right\} \mathrm{ve} D_{2 t}=\left\{\begin{array}{l}0 \text { if } t \leq\left[n \tau_{2}\right] \\ 1 \text { if } t>\left[n \tau_{2}\right]\end{array}\right\}$.

Bilinmeyen parametrelerle $\tau_{1} \epsilon(0,1)$ ve $\tau_{2} \epsilon(0,1)$ rejim değişim noktasının zamanlamasını göstererek tamsayı kısmını belirtmektedir. Test "eşbütünleşme yoktur" temel hipotezini sınamaktadır. Eşbütünleşme yoktur temel hipotezini test etmek için $\mathrm{ADF}, Z_{t}$ ve $Z_{a}$ test istatistikleri kullanılmaktadır (Hatemi-j, 2008: 499).

\subsection{Uzun Dönem Eşbütünleşme Katsayılarının Tahmini}

Eşbütünleşik değişkenler söz konusu olduğunda, çalışmada kullanılan çeşitli değişkenler için uzun dönem katsayıların tahmin edilmesi önemlidir. Bu amaçla Dinamik En Küçük Kareler (DOLS) (Hansen, 1992a, 1992b; Phillips ve Hansen, 1990), Tam Değiştirilmiş En Küçük Kareler (FMOLS) (Saikkonen, 1992; Stock ve Watson, 1993) ve Kanonik Eşbütünleşme Regresyonu (CCR) (Park, 1992) tahmin yöntemleri kullanılmıştır. FMOLS modeli Denklem 13 'te gösterilmektedir.

$$
\begin{aligned}
& \ln y_{t}=\beta_{0}+\beta_{1} \ln k_{t}+\beta_{2} \operatorname{lnh} h_{t}+\beta_{3} \ln u_{t}+\sum_{i=-q}^{q} \delta_{i} \Delta \ln k_{t-i}+\sum_{i=-q}^{q} \delta_{i} \Delta \ln h_{t-i}+ \\
& \sum_{i=-q}^{q} \Delta \ln u_{t-i}+\omega D_{i}+\mu_{t}
\end{aligned}
$$

Denklem 13'te $t$, zaman trendi $q$, gecikme uzunluğu Schwarz bilgi kriteri (SIC) kullanılarak belirlenmektedir. $D_{i}$, GH eşbütünleşme test sonuçlarından elde edilen kırılma tarihini gösteren kukla değişkendir. Böylece, kırılma yıllarının uzun dönem modelde 
istatistiksel olarak anlamlı bir etki gösterip göstermediğini araştırmak mümkündür. FMOLS modeli, seri korelasyon etkisini ve bir eşbütünleşme ilişkisinin varlığından kaynaklanan içsellik problemini dikkate almanın yanı sıra örneklemden sapmadan kaynaklanan hatayı düzeltme avantajına sahiptir (Narayan ve Narayan, 2005).

Park (1992) tarafından geliştirilen CCR eşbütünleşme tahmincisi FMOLS tahmin sonuçlarının sağlamlığını test etmek için kullanılmıştır. Han (1996) CCR yönteminin, modeli dönüştürdüğü dikkate alındığında hata terimlerinin sıfır frekansta diğer değişkenlerle ilişkili olmadığını ileri sürmektedir. Bu nedenle FMOLS ile karşılaştırıldığında CCR tahminleri daha güvenilir, parametreleri daha etkili ve tahmin edilen ki-kare testleri gürültülü olmayan parametrelerdir (Rahman vd., 2020). FMOLS, DOLS ve CCR yalnızca I(1) değişkenleri arasındaki eşbütünleşme koşulu karşılandığında uygulanabilir (Tursoy ve Faisal, 2018).

\subsection{Hacker ve Hatemi-J (2006) Bootstrap Nedensellik Testi}

Hacker-Hatemi-J (2006), Toda-Yamamoto (1995) nedensellik testine dayanarak, bootstrap tekniğiyle veri setine uygun kritik değerlerin hesaplandığı bir nedensellik yöntemi geliştirmiştir. $\mathrm{Bu}$ yöntem değişkenlerin eşbütünleşme derecelerine duyarlı olmayan ve az gözlem sayısı ile sağlıklı sonuçlar veren bir nedensellik testi olarak kabul görmektedir. Hacker-Hatemi-J bootstrap nedensellik testinde Toda-Yamamoto tarafından önerilen Wald istatistiğinin modifiye edilmiş (MWALD) hali Denklem 14'deki gibidir:

$M W A L D=\left(C \hat{\beta}^{\prime}\left[C\left(\left(Z^{\prime} Z\right)^{-1} \oplus S_{U}\right) C^{\prime}\right]^{-1}(C \hat{\beta})\right.$

Burada $\oplus$ knocker çarpan1; C, $\operatorname{pxn}(1+\mathrm{n}(\mathrm{p}+\mathrm{d}))$ matrisidir. MWALD test istatistiğ $\mathrm{i}$ asimptotik $\chi^{2}$ dağılımına sahip olup Granger anlamında yokluk hipotezi:

$H_{0}=C \hat{\beta}=0$

MWALD istatistiği kritik değerinden büyük olduğunda bootstrap simülasyonuna dayalı yokluk sıfır hipotezi reddedilmektedir (Hacker ve Hatemi-J, 2006: 1493).

\section{Ampirik Sonuçlar}

\subsection{Birim Kök Test Sonuçları}

Geleneksel birim kök testleri Tablo 3'te gösterilmektedir. Tablo'da $\Delta$, birinci farkı temsil etmektedir. ADF ve PP testlerine göre \%1 anlamlılık düzeyinde tüm değişkenler I(1) seviyesinde durağandır. 
Tablo 3. Geleneksel Testler (ADF, PP)

\begin{tabular}{|c|l|l|l|l|}
\hline \multirow{2}{*}{ Değişkenler } & \multicolumn{2}{|c|}{$A D F$} & \multicolumn{2}{c|}{$P P$} \\
\cline { 2 - 5 } & \multicolumn{1}{|c|}{-istatistik } & p-olasıllk & t-istatistik & $p$-olasıllk \\
\hline $\operatorname{lny}$ & -2.124 & 0.5103 & -2.165 & 0.4888 \\
\hline $\ln k$ & -2.367 & 0.3871 & -2.406 & 0.3683 \\
\hline $\ln u$ & -3.133 & 0.1236 & -3.884 & 0.0271 \\
\hline $\ln h$ & -3.027 & 0.1435 & -3.027 & 0.1435 \\
\hline$\Delta \ln y$ & -5.208 & 0.0014 & -5.208 & 0.0014 \\
\hline$\Delta \ln k$ & -5.407 & 0.0009 & -5.408 & 0.0009 \\
\hline$\Delta \ln h$ & -7.768 & 0.0000 & -7.066 & 0.0000 \\
\hline
\end{tabular}

Not:Her iki test için sabit ve trendli model tercih edilmiştir. Kritik değerler MacKinnon (1996)'ya göre bakılmıştır. Sırasıyla \%1 ve \%5 anlamlılık düzeyinde kritik değerler -4.04 ve -3.45 'tir. ADF testinde maksimum 6 gecikme alınarak, gecikme kriteri Schwarz bilgi ölçütüne göre seçilmiştir. PP testinde ise bilgi ölçütü Neweywest Bandwicth'e göre seçilmiştir.

Geleneksel testlerin ardından yapısal kırılmanın dikkate alındığı ve test istatistiklerini endojen kabul eden Zivot-Andrews birim kök testi (Tablo 4) yapılmıştır. Tabloda $T_{B}$ kırılma zamanını göstermektedir. Model A sabitte, Model C ise hem sabitte hem de trendde kırılmayı temsil etmektedir. Model A ve C'ye göre düzeyde $\ln u$ ve $\operatorname{lnh}$, birinci farkta ise $\ln k$ için birim kök boş hipotezi reddedilmektedir.

Tablo 4. Zivot-Andrews Birim Kök Testi

\begin{tabular}{|c|l|c|l|c|l|c|c|c|}
\hline \multirow{2}{*}{ Değişkenler } & \multicolumn{4}{|c|}{ Düzey } & \multicolumn{4}{c|}{ Birinci Fark } \\
\cline { 2 - 9 } & \multicolumn{2}{|c|}{ Model A } & \multicolumn{2}{c|}{ Model C } & \multicolumn{3}{c|}{ Model A } & \multicolumn{3}{c|}{ Model C } \\
\cline { 2 - 9 } & $t$-istatistik & $T_{B}$ & $t$-istatistik & $T_{B}$ & $t$-istatistik & $T_{B}$ & $t$-istatistik & $T_{B}$ \\
\hline $\ln y$ & $-3.16(0)$ & 1999 & $-3.85(0)$ & 1999 & $-3.75(2)$ & 2003 & $-4.26(2)$ & 2003 \\
\hline $\ln k$ & $-3.67(0)$ & 1998 & $-4.17(0)$ & 2004 & $-6.10(0)^{* * *}$ & 2003 & $-6.19(0)^{* * *}$ & 2002 \\
\hline $\ln u$ & $-6.92(1)^{* * * *}$ & 1998 & $-7.84(1)^{* * *}$ & 2004 & $-8.10(2)^{* * * *}$ & 2002 & $-10.39(2)^{* * *}$ & 1999 \\
\hline $\ln h$ & $-7.12(0)^{* * *}$ & 2013 & $-9.71(0)^{* * *}$ & 2013 & $-6.11(0)^{* * *}$ & 2013 & $-10.38(0)^{* * *}$ & 2013 \\
\hline
\end{tabular}

Not: Tablo kritik değerleri Model A için \%1: -5.34, \%5: -4.93, \%10: -4.58; Model C için \%1: -5.57, \%5: -5.08, \%10: -4.82'dir. Parantez içindeki değerler gecikme uzunluğudur. ***,**,* sırasıyla \%1, \%5 ve \%10 anlamlılık düzeylerini göstermektedir.

İki kırılma içeren ve kırılma zamanının içsel olarak belirlendiği Lee-Strazicich birim kök testine göre, (Tablo 5) t-istatistik değerleri tablo kritik değerinden büyük olduğunda (mutlak değer) birim kök olduğunu söyleyen yokluk hipotezi reddedilmektedir.

Model AA sonuçlarına göre düzeyde tüm değişkenler için boş hipotez reddedilmiştir. Model CC'de ise lny ve lnk birinci farkta durağandır. Tabloda $\mathrm{T}_{\mathrm{B} 1}$ ve $\mathrm{T}_{\mathrm{B} 2}$ kırılma zamanlarını göstermektedir.

Tablo 5. Lee-Strazicich İki Kırılmalı Birim Kök Testi

\begin{tabular}{|c|l|l|l|l|l|l|}
\hline Değişkenler & \multicolumn{3}{|c|}{ Model AA } & \multicolumn{3}{c|}{ Model CC } \\
\hline & t-istatistik & $T_{B 1}$ & $T_{B 2}$ & t-istatistik & $T_{B 1}$ & $T_{B 2}$ \\
\hline Iny & $-3.70(2)^{* *}$ & 1998 & 2009 & $-5.33(2)$ & 1999 & 2013 \\
\hline Ink & $-4.15(2)^{* * *}$ & 1997 & 2001 & $-5.16(2)$ & 1999 & 2004 \\
\hline
\end{tabular}




\begin{tabular}{|c|l|l|l|l|l|l|}
\hline $\ln u$ & $-8.02(1)^{* * *}$ & 1995 & 1997 & $-10.91(2)^{* * * *}$ & 2000 & 2010 \\
\hline $\ln h$ & $-3.89(2)^{* *}$ & 2010 & 2013 & $-7.44(2)^{* * *}$ & 2006 & 2011 \\
\hline$\Delta \ln y$ & $-5.38(0)^{* * *}$ & 1995 & 2002 & $-5.93(0)^{* *}$ & 1995 & 2001 \\
\hline$\Delta \ln k$ & $-5.77(0)^{* * *}$ & 1995 & 1997 & $-6.21(0)^{* *}$ & 1995 & 2001 \\
\hline$\Delta \ln u$ & $-3.51(2)^{*}$ & 1997 & 2000 & $-6.96(2)^{* * *}$ & 1998 & 2002 \\
\hline$\Delta \ln h$ & $-5.63(0)^{* * *}$ & 1995 & 2009 & $-26.3(1)^{* * *}$ & 2010 & 2014 \\
\hline
\end{tabular}

Not: Tablo kritik değerleri Model AA için $\% 1, \% 5$ ve \%10 anlamlılık düzeyinde sırasıyla $-4.07,-3.56,-3.30$; Model CC için $-6.82,-5.92$ ve -5.54 'tür. Parantez içindeki değerler gecikme uzunluklarıdır. ***,**,* sırasıyla $\% 1, \% 5$ ve $\% 10$ anlamlılık düzeylerini göstermektedir.

\subsection{Gregory-Hansen Eşbütünleşme Test Sonuçlart}

Tablo 6'da, GH'nin yapısal kırılmalı eşbütünleşme test sonuçları görülmektedir. Model C sabit terimde ve Model C/T yalnızca sabit terim ve eğimde yapısal değişimi içerirken; Model C/S sabit terim ve eşbütünleşme eğim katsayılarında (rejim) değişimi içermektedir. Model C dikkate alındığında hesaplanan minimum $\mathrm{ADF}^{*}$ test istatistiği mutlak değer olarak kritik değerlerden küçük olduğundan yokluk hipotezi reddedilememektedir. Model C/T için ADFtest istatistiği $\% 10, Z_{t}$ için $\% 5$ anlamlılık düzeyinde; Model $\mathrm{C} / \mathrm{S}$ için hem ADF* hem de $Z_{t}$ test istatistikleri mutlak değer olarak \%5 anlamlılık düzeyinde kritik değerden büyük olduğu için yokluk hipotezi reddedilmektedir.

Tablo 6. Gregory-Hansen Yapısal Kırılmalı Eşbütünleşme Testi

\begin{tabular}{|c|c|c|c|c|c|c|c|c|}
\hline \multirow[t]{2}{*}{ Model } & \multirow{2}{*}{$\begin{array}{l}\text { ADF- } \\
\dot{\text { Istatistiği }} \\
T_{B}\end{array}$} & \multirow{2}{*}{$\begin{array}{l}Z_{t} \\
T_{B}\end{array}$} & \multicolumn{3}{|c|}{ Kritik Değerler } & \multirow{3}{*}{\begin{tabular}{c}
\multicolumn{1}{c}{$Z_{a}$} \\
$T_{B}$ \\
\\
21.472 \\
2007
\end{tabular}} & \multicolumn{2}{|c|}{ Kritik Değerler } \\
\hline & & & $\% 1$ & $\% 5$ & & & $\% 1$ & $\% 5$ \\
\hline$C$ & $\begin{array}{l}-4.446(1) \\
2000\end{array}$ & $\begin{array}{l}-3.789 \\
2000\end{array}$ & -5.77 & -5.28 & -5.02 & & -63.64 & -53.58 \\
\hline$C / T$ & $\begin{array}{l}-5.516(0) * \\
2002\end{array}$ & $\begin{array}{l}-5.634 * * \\
2002\end{array}$ & -6.05 & -5.57 & -5.33 & $\begin{array}{l}-28.514 \\
2002\end{array}$ & -70.27 & -59.26 \\
\hline$C / S$ & $\begin{array}{l}-6.34(0) * * \\
2000\end{array}$ & $\begin{array}{l}-6.464 * * \\
2000\end{array}$ & -6.51 & -6.00 & -5.75 & $\begin{array}{l}-33.357 \\
2000\end{array}$ & -80.15 & -68.94 \\
\hline
\end{tabular}

Not: Kritik değerler Gregory ve Hansen (1996) Tablo 1'den alınmıştır. Parantez içindeki değerler Akaike Bilgi kriteri tarafından seçilen gecikme sayısını göstermektedir. $\mathrm{T}_{\mathrm{B}}$ kırılma noktasını göstermektedir. *** ve $* *$, sırasıyla \%1 ve \%5 düzeyde istatistiksel anlamlılı̆̆ gösterir.

\subsection{Hatemi-J Test Sonuçlart}

Açıklayıcı değişkenler aynı seviyede durağan olduklarında, iki bilinmeyen rejim kaymalı eşbütünleşme ilişkisinin olup olmadığı HJ yaklaşımı ile sınanabilir. İki yapısal kırılmalı eşbütünleşme hipotezi reddedildiğinde bir yapısal kırılmalı GH yaklaşımı uygulanmaktadır (Zhao vd., 2017). Tablo 7'de HJ test sonuçları değişkenler arasında eşbütünleşme ilişkisi yoktur sıfır hipotezinin reddedilemediğini göstermektedir. Dolayısıyla değişkenler arasında iki yapısal kırılmayla birlikte eşbütünleşme ilişkisinin olmadığı ifade edilebilir. 
Tablo 7. Hatemi-J (2008) Eşbütünleşme Testi Sonuçları (Rejim Değişimi Modeli-C/S)

\begin{tabular}{|c|c|c|c|c|c|}
\hline \multirow[t]{2}{*}{ Test İstatistiği } & \multirow{2}{*}{$\begin{array}{l}\text { Tahmin Edilen } \\
\text { Test Değeri }\end{array}$} & \multicolumn{3}{|c|}{ Kritik Değerler } & Kırılma \\
\hline & & $\% 1$ & $\% 5$ & $\% 10$ & Tarihleri \\
\hline$A D F^{*}$ & $-5.194(1)$ & -7.833 & -7.352 & -7.118 & 1994,1998 \\
\hline$Z_{t}^{*}$ & -5.302 & -7.833 & -7.352 & -7.118 & 1998,2007 \\
\hline$Z_{\alpha}^{*}$ & -28.648 & -118.577 & -104.860 & -97.749 & 1998, 2007 \\
\hline
\end{tabular}

Not: Kritik değerler Hatemi-J (2008) Tablo 1'den alınmıştır.

Böylece çalışmada GH testinde Model C/T için bulunan eşbütünleşme ilişkisi dikkate alınarak, uzun dönem katsayılarının elde edilmesinde FMOLS, DOLS ve CCR eşbütünleşme tahmincileri kullanılmıştır.

\subsection{Eşbütünleşme Katsayılarının Tahmin Edilmesi}

GH testinde yapısal kırılmaları dikkate alan eşbütünleşme testi gereği C/T modeliyle çalışılmıştır. Kukla değişken modele dahil edilirken kırılmanın gerçekleştiği tarihe kadar sıfır değeri, kırılma tarihi sonrası için bir değeri verilmiştir. Denklem (15) yapısal kırılmanın $\left(\varphi_{t}\right)$ dahil olduğu modeli göstermektedir.

$\ln y_{t}=\mu_{1}+\mu_{2} \varphi_{t}+\beta t+\gamma_{1} \ln k_{t}+\gamma_{2} \ln u_{t}+\gamma_{3} \operatorname{lnh} h_{t}+\varepsilon_{t}$

(15) Numaralı tahmin denklemnden elde edilen sonuçlar Tablo 8'de görülmektedir. Model $\mathrm{C} / \mathrm{T}$ için FMOLS tahmininden elde edilen sonuçlar lnu değişkeni dışında tüm değişkenlerin istatistiksel olarak anlamlı olduğunu ortaya koymaktadır. Tablo 8'de tahmin edilen DOLS modeli sonuçları tüm değişkenler için istatistiksel olarak anlamlı sonuçlar üretirken, CCR modeli bulguları FMOLS ile benzer bir sonuç ortaya koymuştur.

Kukla değişken ile kişi başına GSYİH arasında beklendiği gibi her üç modelde negatif bir ilişki vardır. Türkiye'de 2002 yılı, 2001 krizinin etkilerini taşımaktadır. Örneğin Türkiye'nin AB tanımlı genel yönetim borç stokunun GSYİH'ye oranı 2002Ç4 döneminde \% 71.5'dir (T.C. Hazine ve Maliye Bakanlığı, 2020). lnu değişkeni FMOLS ve CCR tahminlerinde negatif ancak istatistiksel olarak anlamsızken, DOLS tahmininde negatif ve anlamlıdır. Burada beşeri sermayenin eğitim boyutuna ilişkin alınan yetişkin üniversite düzeyinin büyüme üzerindeki etkisinin negatif olması, Türkiye'de mevcut koşullar altında düşük işgücü üretkenliğine işaret etmektedir. Bu bulgunun önemli bir politika sonucu ekonomik büyümenin teşvik edilmesinde üniversitelerde eğitim kalitesinde iyileştirmeye ihtiyaç olduğudur. Ayrıca hem kamu hem özel sektörün daha fazla mezun üniversite öğrencisi istihdam etmek üzere katma değeri yüksek olan ilgili sektörlere daha fazla yatırım yapması önemli görünmektedir. 
Tablo 8. FMOLS, DOLS ve CCR Tahmin Sonuçları (Model C/T)

\begin{tabular}{|c|c|c|c|}
\hline \multicolumn{4}{|c|}{$\ln y_{t}=\mu_{1}+\mu_{2} \varphi_{t}+\beta t+\gamma_{1} \ln k_{t}+\gamma_{2} \ln u_{t}+\gamma_{3} \ln h_{t}+\varepsilon_{t}$} \\
\hline Bağımlı Değişken: lny & FMOLS & $D O L S$ & $C C R$ \\
\hline$C$ & $\begin{array}{l}3.389(0.095)^{*} \\
{[1.938]}\end{array}$ & $-24.253(0.014) * *$ & $3.389(0.110)$ \\
\hline$\beta t$ & $\begin{array}{l}0.025(0.000) * * * \\
{[0.004]}\end{array}$ & $0.013(0.013)^{* *}$ & $0.025(0.000) * * *$ \\
\hline$\varphi_{t}(2002)$ & $\begin{array}{l}-0.062(0.000) * * * \\
{[0.013]}\end{array}$ & $-0.026(0.014) * *$ & $-0.059(0.000)^{* * *}$ \\
\hline $\ln k_{t}$ & $\begin{array}{l}0.456(0.000) * * * \\
{[0.032]}\end{array}$ & $0.901(0.004) * * *$ & $0.468(0.000) * * *$ \\
\hline $\ln u_{t}$ & $\begin{array}{l}-0.051(0.319) \\
{[0.050]}\end{array}$ & $-0.718(0.013) * *$ & $-0.049(0.308)$ \\
\hline $\operatorname{lnh} h_{t}$ & $\begin{array}{l}1.108(0.026)^{* *} \\
{[0.464]}\end{array}$ & $7.622(0.008) * * *$ & $1.099(0.035)^{* *}$ \\
\hline $\operatorname{Adj.} R^{2}$ & 0.99 & 0.99 & 0.99 \\
\hline
\end{tabular}

Not: Köşeli parantez içerisindeki değerler standart hataları, parantez içindeki değerler p-olasıllk değerlerini göstermektedir. ***, **, * sırasıyla $\% 1, \% 5$ ve $\% 10$ düzeyinde katsayıların istatistiksel olarak anlamlılığ temsil etmektedir. FMOLS, DOLS ve CCR için uzun dönemli varyans matrisinin hesaplanmasında Newey-West otomatik bant genişliği (bandwith) seçimi kullanılmıştır. Gecikmeler Schwartz bilgi kriterine göre belirlenmiştir. Tahmindeki otokorelasyon sorunu fark alma yöntemi ile giderilmiştir. Kukla değişken olarak analizde, GH eşbütünleşme testinde $\mathrm{C} / \mathrm{T}$ modelinde tespit edilen $\mathrm{D}_{\mathrm{t}}$ : 2002 alınmıştır.

\subsection{Hacker ve Hatemi-J (2006) Bootstrap Nedensellik Test Sonuçlart}

Toda-Yamamoto'ya göre (1995), modele ilave sınırsız gecikmeler dahil edildiği sürece, VAR çerçevesi içindeki bütünleşik değişkenler arasındaki Granger nedenselliğinin test edilmesi için eşbütünleşme bir ön koşul değildir. Tablo 9'da Hacker-Hatemi-J (2006) tarafından önerilen doğrusal bootstrap temelli Toda-Yamamoto nedensellik test sonuçları yer almaktadır.

Tablo 9. Hacker-Hatemi-J (2006) Bootstrap Nedensellik Test Sonuçları

\begin{tabular}{|l|l|l|l|l|}
\hline \multirow{2}{*}{ Model } & \multirow{2}{*}{ MWALD } & \multicolumn{3}{c|}{ Kritik Dĕgerler } \\
\cline { 3 - 5 } & & $\% 1$ & $\% 5$ & $\% 10$ \\
\hline $\ln y \nRightarrow \ln k$ & 0.619 & 8.653 & 4.330 & 2.957 \\
\hline $\ln k \nexists \ln y$ & 0.135 & 8.387 & 4.319 & 2.933 \\
\hline $\ln y \nRightarrow \ln u$ & 4.944 & 11.595 & 7.013 & 5.131 \\
\hline $\ln u \nRightarrow \ln y$ & $28.028 * * *$ & 12.408 & 7.105 & 5.246 \\
\hline $\ln y \nexists \ln h$ & 0.232 & 9.011 & 4.445 & 3.017 \\
\hline $\ln h \nRightarrow \ln y$ & 0.790 & 8.146 & 2.941 & 2.941 \\
\hline $\ln h \nRightarrow \ln k$ & 0.133 & 9.366 & 4.430 & 2.913 \\
\hline $\ln k \nexists \ln h$ & 0.052 & 10.163 & 4.792 & 3.054 \\
\hline $\ln h \nRightarrow \ln u$ & 1.716 & 8.819 & 4.655 & 3.098 \\
\hline $\ln u \nRightarrow \ln h$ & 2.136 & 11.136 & 5.259 & 3.352 \\
\hline
\end{tabular}

Not: Bootstrap kritik değerleri 10.000 tekrarlı yapılmıştır. Optimal gecikme uzunluğu için Hatemi-J bilgi kriteri kullanılmıştır. dmax. (bütünleşme derecesi) $=1$.

MWALD istatistik değerleri sadece $\ln u$ değişkeninden lny değişkenine doğru \%1 anlamlılık düzeyinde tek yönlü Granger nedensellik ilişkisinin varlığını kanıtlamaktadır. Bu sonuç, Türkiye'de yetişkin üniversite eğitim düzeyinin daralmasına yönelik faaliyetlerin kişi başına gelir üzerinde olumsuz etki yaratacağına işaret etmektedir. Üniversite eğitimi almış 
yetişkinlerin gençlerle eşit şartlarda ve yaşa uygun yollarla öğrenme firsatlarına sahip olmaları, yeteneklerinin tanınması ve kullanılması açısından önemlidir (Yang vd., 2015:6). Dolayısıyla üniversitelere erişimin artırılması dışında yüksek öğretim sisteminin yetişkin öğrencilerin öğrenmeyi sürdürecekleri bir ortamı kolaylaştırması gerekmektedir. Tersine bir nedenselliğe ilişkin bir bulgu elde edilememiştir.

\section{Sonuç}

Bu çalışmada öncelikle sağlık ve eğitim ile temsil edilen beşeri sermaye ile ekonomik büyüme arasındaki ilişkinin teorik çerçevesi tartışılmış; ardından Türkiye'de 1991-2018 dönemi için derlenmiş veri seti kullanılarak ampirik analiz yapılmıştır. Çalışmamız mevcut çalışmalardan farklı olarak, beşeri sermaye gelişiminin bir temsilcisi olarak yetişkin üniversite eğitim düzeyinin büyüme üzerindeki etkisini tahmin etmiştir. Böylece insan kaynakları ve yenilik kapasitesi arasındaki bağlantının ekonomik büyümeye yansıyıp yansımadığı tespit edilmiştir. Yüksek eğitim seviyelerinin kuruluşların belirli hedefleri ile ilgili olması nedeniyle, inovasyon kapasitesinin belirlenmesinde diğer eğitim vekil değişkenlerine göre daha iyi bir değişken olabilir. Ayrıca çalışmada nedensellik analizinde daha güvenilir kritik değerlerin elde edilmesinde bootstrap yaklaşımını kullananan Hacker ve Hatemi-J (2006) nedensellik analizi kullanılmıştır. Bu yaklaşım otoregresif koşullu heteroskedasiteyi (ARCH) dikkate alan ve normallik varsayımına duyarlı olmayan oldukça sağlam bir yaklaşım sunmaktadır.

Eşbütünleşme analizi sonrasında eşbütünleşme katsayılarının tahmini için kullanılan FMOLS, DOLS ve CCR model bulguları yükseköğretim dışında sabit sermaye yatırımları ve doğumda yaşam beklentisinin ekonomik büyüme üzerindeki etkisinin pozitif ve istatistiki olarak anlamlı olduğunu ortaya çıkarmıştır. Yaşam süresinin artması sağlıklı ve üretken bir işgücü ve fiziksel sermaye birikimini artırmak yoluyla ekonomik büyümeye pozitif katkı sağlamaktadır. Ancak nedenselliğe ilişkin bir kanıt elde edilememiştir. Diğer yandan DOLS tahmin sonuçları Türkiye'de beşeri sermayenin ekonomik büyüme üzerindeki etkisinin negatif olduğunu göstermiştir. Ekonomik büyümeyi etkileyecek kanallar olan üretken beceri ve yeteneklerin birikimi, yenilik kanalıyla yeni bilginin üretilmesi ve yeni teknolojilere adaptasyon yeteneğinin Türkiye örneğinde geçerli olmadığı anlaşılmaktadır. Literatürde daha yüksek eğitimli bireylerin işgücü piyasasındaki risklere karşı daha iyi korunduğu ve daha düşük işsizlik oranlarına sahip olduğu kabul edilse de, bulgularımız Türkiye gibi genç işsizliğin yüksek olduğu bir ülkede beşeri sermayenin büyümeye katkı sağlamadığ1 yönündedir. $\mathrm{Bu}$ çalışmanın bulgularından önemli politika dersleri çıkarılabilir. Yükseköğretimin üretkenlik artışlarının nedeni ve ekonomik büyümeyi yönlendiren 
inovasyon kaynağı olarak görülmesi nedeniyle yükseköğretimin genişletilmesi çekici bir hükümet politikasıdır. Ancak buradaki en önemli nokta yükseköğretimi genişletmenin daha fazla eğitim yılı eklemek olmadığıdır. Eğitimin niteliğinin iyileştirilmesi yanı sıra yüksek eğitimli bireylerin bilişsel yeteneklerini kullanabileceği sektörlerin ülke geneline yayılması bu sonucu tersine çevirecek etki sağlayabilir.

Pritchett'e göre (2001) eğitimin kalkınma etkisinin beklentilerin altında kalmasının olası nedeninden biri eğitim kalitesinin düşük olması ve eğitim yıllarının beşeri sermaye birikimi yaratmamasıdır. Dolayısıyla eğitime yıl eklerken bilişsel becerilere yatırım yapılması önemlidir. Nedensellik test sonuçlarımızın yüksek eğitimden büyümeye doğru tek yönlü olması, yetişkin yüksek eğitim düzeyinde olası engellerin büyüme üzerinde olumsuz bir etki yaratacağı yönündedir. Türkiye'de yüksek öğretimde artan heterojenlik, sürekli eğitim ve öğretim sistemleri ile tamamlanmaya çalışılmaktadır. Öğrencilerin işgücü piyasası fırsatlarını iyileştirmeyi amaçlayan tamamlayıcı eğitim paketlerinin artması önemlidir. Böylece temel bulgularımız Türkiye'de büyüme sürecinde eğitimin marjinal rolü şeklinde yorumlamak yerine, Kumar'ın (2006) belirttiği gibi eğitimin daha iyi tahmin edilme ihtiyacını da ortaya koymaktadır. Okullaşmanın kalitesi ve mesleki deneyim gibi değişkenlerin yanı sıra eğitim hizmetlerinin eşit olarak dağıtılma yeteneği dikkate alınabilir. Ram'in (2007) belirttiği gibi entelektüel faktörlerin büyüme üzerindeki etkisi, yaşam beklentisi ve eğitimden daha yüksek olabilir. Sonuçlarımıza dayanarak, eğitimin nicel yönlerinin yanında önemli ölçüde nitel yönlerinin de geliştirilmesi gerektiğini, bilişsel yeteneğin kullanımını artıracak çalışma ortamlarının çoğalmasını ve sağlığın pozitif etkisi ile birlikte dikkate alındığında yükseköğretimin ekonomik büyümeye etkilerinin pozitif yönde değişebileceğini ifade etmek mümkündür. 


\section{KAYNAKÇA}

Abdioğlu, Zehra ve Albayrak, Nilcan. 2018. "Türkiye'de Yükseköğretimin Sektörel Büyümeye Etkisi." Uluslararası İktisadi ve İdari İncelemeler Dergisi 127-140.

Adu, George. 2013. "Determinants of Economic Growth in Ghana: Parametric and Nonparametric Investigations." The Journal of Developing Areas 47(2), 277- 301.

Aghion, Philippe ve Peter Howitt. 1992. "A Model of Growth Through Creative Destruction." Econometrica 60(2), 323-351.

Ak, Rengin. 2012. "The Relationship between Health Expenditures and Economic Growth: Turkish Case." International Journal of Business Management \& Economic Research 3(1), 404-409.

Aka, Bedia F. ve Dumont, J.C. 2008. "Health, Education and Economic Growth: Testing for Longrun Relationships and Causal Linksin the United States." Applied Econometrics and International Development 8(2), 101-110.

Ay, Ahmet ve Yardımcı, Pınar. 2008. “Türkiye'de Beşeri Sermaye Birikimine Dayalı Ak Tipi İçsel Ekonomik Büyümenin VAR Modeli ile Analizi (1950-2000).” Maliye Dergisi 155: 39-54.

Awel, Ahmed Mohammed. 2013. "The Long-Run Relationship between Human Capital and Economic Growth in Sweden.’MRPA Paper No. 45183.

Barro, Robert J. 1991. "Economic Growth in a Cross Section of Countries."Quarterly Journal of Economics106(2), 407-443.

Barro, Robert J. ve Sala-i-Martin, Xavier. 1995.Economic Growth.New York: McGraw-Hill.

Barro, Robert J. 1996. "Health and Economic Growth."Harvard University.

Barro, Robert J. 1997. Determinants of Economic Growth: A Cross-Country Empirical Study.Cambridge, MA: MIT Press.

Becker, Gary S. 1962. "Investment in Human Capital: A Theoretical Analysis.” Journal of Political Economy 70(5), part 2, 9-49.

Behrman, Jere R. ve Rosenzweig, Mark R. 2004. "Return to Birthweight." The Review of Economics and Statistics 86(2), 586-601.

Bhargavaa, Alok, Jamison, Dean T., Lau, Lawrence J. ve Murray, Christopher J.L. 2001. "Modeling the Effects of Health on Economic Growth." Journal of Health Economics 20: 423-440.

Bils, Mark ve Klenow, Peter J. 2000. “Does Schooling Cause Growth?”American Economic Review 90(5), $1160-1183$.

Bleakley, Hoyt. 2007. "Disease and Development: Evidence from Hookworm Eradication in the American South.” The Quarterly Journal of Economics 22(1), 73-117.

Bloom, David E., Canning, David ve Sevilla, Jaypee. 2004. "The Effect of Health on Economic Growth: A Production Function Approach." World Development 32(1), 1-13.

Bloom, David E., Canning, David, Kotschy, Rainer, Prettner, Klaus ve Schünemann, Johannes. 2018. "Health and Economic Growth: Reconciling the Micro and Macro Evidence." IZA DP No. 11940.

Boachi, Micheal K. 2017. "Health and Economic Growth in Ghana: An Empirical Investigation." Fudan Journal of the Humanities and Social Sciences 10: 253-265.

Bowen, William M. ve Qian, Haifeng. 2017. "State Spending for Higher Education: Does it Improve Economic Performance?” Regional Science Policy \& Practice 9(1), 7-23.

Carrin, G. 1984. "Economic Evaluation of Health Care in Developing Countries." Journal of Political Economy 80: $223-255$.

Dănăcică, Daniela-Emanuela. 2011. "Causality between School Education and Economic Growth in Romania."Argumenta Oeconomica 1(26), 57-72.

Dănăcică, Daniela-Emanuela, Belașcu, Lucian ve Ilie, Livia. 2010. “The Interactive Causality between Higher Education and Economic Growth in Romania.” International Review of Business Research Papers 6(4), 491-500.

Denison, Edward F. ve Poullier, Jean-Pierre. 1967. Why Growth Rates Differ. Postwar Experience in Nine Western Countries, Washington DC, Brookings Institution.

Ehrlich, Isaac ve Lui, Francis T. 1991. "Intergenerational Trade, Longevity, and Economic Growth.” Journal of Political Economy 99: 1029-59.

Erdem, Ekrem ve Tugcu, Can T. 2012. "Higher Education and Unemployment: A Cointegration and Causality Analysis of the Case of Turkey." European Journal of Education 47(2), 299-309.

Erdoğan, Seyfettin ve Yıldırım, Durmuş Ç. 2009. "Türkiye'de Eğitim-İktisadi Büyüme İlişkisi Üzerine Ekonometrik Bir İnceleme.” Bilgi Ekonomisi ve Yönetimi Dergisi 4(2), 11-22.

Gemmell, Norman. 1995. "Endogenous Growth, the Solow Model and Human Capital." Economics of Planning 28: 169-183.

Goldin, Claudia D. 2016. "Human Capital." In edited by C. Diebolt and M. Haupert, M. Handbook of Cliometrics,55-86. Berlin: Springer-Verlag. 
Greiner, A., Semmlery, W., ve Gong, G. 2005.Economic Growth: A Time Series Perspective, Princeton University Press.

Gregory, Allan W. ve Hansen Bruce E. 1996. "Residual-Based Tests for Cointegration in Models with Regime Shifts." Journal of Econometrics 70: 99-126.

Grossman, Michael. 1972.“'On the Concept of Health Capital and the Demand for Health.”Journal of Political Economy 80: 223-55.

Hacker, R. Scott ve Hatemi-J, Abdulnasser. 2006. “Tests for Causality between Integrated Variables Using Asymptotic and Bootstrap Distributions: Theory and Application.” Applied Economics 38(13), 14891500.

Hamdan, Allam, Sarea, Adel, Khamis, Reem ve Anasweh, Mohammad. 2020. "A Causality Analysis of the Link between Higher Education and Economic Development: Empirical Evidence.” Heliyon 6: 1-6.

Han, Hsiang-Ling. 1996. "Small Sample Properties of Canonical Cointegrating Regressions." Empirical Economics 21(2), 235-253.

Hansen, Bruce E. 1992 (a). "Efficient Estimation and Testing of Cointegrating Vectors in the Presence of Deterministic Trends". Journal of Econometrics 53 (1-3), 87-121.

Hansen, Bruce E. 1992 (b). "Tests for Parameter Instability in Regressions with I(1) Processes.” Journal of Business and Economic Statistics 10(3), 321-335.

Hanushek, E.A. ve Wößmann, L. 2007. "The Role of Education Quality in Economic Growth.” World Bank Policy Research Working Paper 4122.

Hanushek, E. A. ve Woessmann, L. 2010. "Education and Economic Growth.” In International Encyclopedia of Education (Vol. 2) edited by P. Peterson, E. Baker, B. McGaw, 245-252). Oxford: Elsevier.

Hanushek, Eric A. 2016. "Will More Higher Education Improve Economic Growth?" Oxford Review of Economic Policy 32(4), 538-552.

Harmon, Colm, Oosterbeek, Hessel ve Walker, Ian. 2003. “The Returns to Education: Microeconomics.” Journal of Economic Surveys 17(2), 115-155.

Hatemi-J, Abdulnasser. 2008. “Tests for Cointegration with Two Unknown Regime Shifts with an Application To Financial Market Integration.” Empirical Economics, 35(3), 497-505.

Hoenack, Stephen A. 1993. "Higher Education and Economic Growth." In Higher Education and Economic Growth, edited by William E. Becker ve Darrell R. Lewis, 21-50.New York: Springer.

Katırcıoğlu, Salih T. 2009. "Investigating Higher-education-led Growth Hypothesis in a Small Island: Time Series Evidence from Northern Cyprus.” EconAnadolu 17-19 Haziran.

Khan, Raza, Salim, H. ve Laila, A. 2019. "Does the Improved Health Can Raise GDP? (A Longitudinal Study of Pakistan Economy) Airlines.”Journal of Economic and Business Studies 2(8), 1-4.

Kim, Dong-Hyeun, Wu, Yi-Chen ve Lin, Shu-Chin. 2017. "Education, Health and Economic Development." Macroeconomic Dynamics 23(2), 837-869.

Kumar, Chandra Shekhar. 2006. "Human Capital and Growth Empirics." The Journal of Developing Areas 40(1), 153-179.

Lee, Junsoo ve StrazicichMark C. 2003. "Minimum Lagrange Multiplier Unit Root Test with Two Structural Breaks." The Review of Economics and Statistics 85(4), 1082-1089.

Li, Hongyi ve Liang, Huang. 2010. "Health, Education, and Economic Growth in East Asia." Journal of Chinese Economic and Foreign Trade Studies 3(2),110-131.

Lucas, Robert E. 1988. “On the Mechanisms of Economic Development.”Journal of Monetary Economics 22(1), 3-42.

Lucas, Robert E. 1993. "Making a Miracle.” Econometrica 61(2), 251-272.

Mackinnon, James G. 1996. "Numerical Distribution Functions for Unit Root and Cointegration Tests.” Journal of Applied Econometrics 11: 601-618.

Mankiw, N. Gregory, Romer, Davidve Weil, David N. 1992."A Contribution to the Empirics of Economic Growth.”Quarterly Journal of Economics 107(2), 407 -437.

Mariana, Dragoescu Raluca. 2015. "Education As a Determinant of the Economic Growth. The Case of Romania." Procedia - Social and Behavioral Sciences 197: 404-412.

Mariz-Pérez, R. M., Teijeiro-Álvarez, M. M., ve García-Álvarez, M. T. (2012). The Importance of Human Capital in Innovation: A System of Indicators. Studies in Fuzziness and Soft Computing Book Series (STUDFUZZ, volume 287).

Marquez-Ramos, Laura ve Mourelle, Estefanía. 2019. "Education and Economic Growth: an Empirical Analysis of Nonlinearities.” Applied Economic Analysis 27(79), 21-45.

Mercan, Mehmet ve Sezer, Sevgi. 2014. "The Effect of Education Expenditure on Economic Growth: The Case of Turkey.” Procedia-Social and Behavioral Sciences 109: 925-930.

Narayan, Paresh Kumar ve Narayan, Seema 2005. "Estimating Income and Price Elasticities of Imports for Fiji in a Cointegration Framework." Economic Modelling 22(3), 423-438.

Nelson, Richard ve Phelps, Edmund. 1966. "Investment in Humans, Technological Diffusion and Economic Growth.”American Economic Review 56(1/2), 69-75. 
Neycheva, Mariya. 2019. "How Might the Negative Impact of Higher Education on Growth Be Explained? The Role of Vertical Qualification (Mis)Match in an MRW-Type Model." Economics of Transition and Institutional Change 27(4), 943-969.

Ogundari, Kolawole ve Awokuse, Titus. 2018. "Human Capital Contribution to Economic Growth in SubSaharan Africa: Does Health Status Matter More Than Education?” Economic Analysis and Policy 58: 131-140.

Park, Joon Y. 1992. “Canonical Cointegrating Regressions.” Econometrica 60(1), 119-143.

Phillips, Peter C.B. ve Hansen, Bruce E. 1990. "Statistical Inference in Instrumental Variables Regressions with I(1) Processes.” Review of Economic Studies 57(1), 99-125.

Pritchett, Lant. 2001. “'Where Has All the Education Gone?” The World Bank Economic Review 15(3), $367-$ 391.

Rahman, Zia Ur, Khattak, Shoukat Iqbal, Ahmas, Manzoor ve Khan, Anwar. 2020. “A Disaggregated-Level Analysis of the Relationship Among Energy Production, Energy Consumption and Economic Growth: Evidence from China.” Energy 194: 1-11.

Ram, Rani.2007. "IQ and Economic Growth: Further Augmentation of Mankiw-Romer-Weil Model." Economics Letters 94(1), 7-11.

Ranis, Gustav, Stewart, Frances ve Ramirez, Alejandro. 2000. "Economic Growth and Human Development." World Development 28(2), 197-219.

Romer, Paul M. 1986. "Increasing Returns and Long-Run Growth.” Journal of Political Economy 94(5), 11021037.

Romer, Paul M. 1990a. "Human Capital and Growth: Theory and Evidence." Carnegie-Rochester Conference Series on Public Policy 32: 251-286.

Romer, Paul M. 1990b.“Endogenous Technological Change.”Journal of Political Economy 98(5),71-102.

Saikkonen, Pentti 1992. "Estimation and Testing of Cointegrated Systems by an Autoregressive Approximation." Econometric Theory 8: 1-27.

Schultz, Theodore W. 1961. "Investment in Human Capital.”American Economic Review 51(1), 1-17.

Schultz, Theodore W. 1963. The Economic Value of Education.New York: Columbia University Press.

Siddique, Hafiz M.A.,Mohey-ud-din, Ghulam ve Kiani, Adiqa. 2018. "Health, Education and Economic Growth Nexus: Evidence from Middle Income Countries.” Global Social Sciences Review 3(4), 68-86.

Solow, Robert M. 1956. "A Contribution to the Theory of Economic Growth." Quarterly Journal of Economics 70: 65-94.

Stock, James H. ve Watson, Mark. 1993. “A Simple Estimator of Cointegrating Vectors in Higher Order Integrated Systems.” Econometrica 61(4), 783-820.

Swan, Trevor W. 1956. "Economic Growth and Capital Accumulation.” Economic Record 32(63), 334-61.

T.C. Hazine ve Maliye Bakanlığı. 2020. AB Tanımlı Genel Yönetim Borç İstatistikleri. https://www.hmb.gov.tr/kamu-finansmani-istatistikleri

Toda, Hiro Y. ve Yamamoto, Taku. 1995. "Statistical Inference in Vector Autoregressions with Possibly Integrated Processes." Journal of Econometrics66:225-250.

Şimşek, Muammer ve Kadılar, Cem. 2010. "Türkiye'de Beşeri Sermaye, İhracat ve Ekonomik Büyüme Arasındaki İlişkinin Nedensellik Analizi.” Cumhuriyet Üniversitesi İktisadi ve İdari Bilimler Dergisi 11(1), 115-140.

Taban, Sami. 2006. “Türkiye'de Sağlık ve Ekonomik Büyüme Arasındaki Nedensellik İlişkisi.” Sosyoekonomi 4(4), 31-46.

Topall1, Nurgün. 2015. “Türkiye'de Beşeri Sermaye ve Büyüme İlişkisinin Ekonometrik Bir Analizi.” Uludağ Üniversitesi İktisadi ve İdari Bilimler Fakültesi Dergisi 34(1), 217-234.

Tursoy, Turgut ve Faisal, Faisal. 2018. "The Impact of Gold and Crude Oil Prices on Stock Market in Turkey: Empirical Evidences from ARDL Bounds Test and Combined Cointegration.” Resources Policy 55: 4954.

Umar, Dominic Ikoh. 2017. "Education Outcomes, Health Outcomes and Economic Growth in Nigeria (19802013)." Journal of Social and Economic Development 19(1), 227-244.

Van Zon, Adriaan ve Muysken, Joan. 2001. "Health and Endogenous Growth." Journal of Health Economics 20: 169-185.

Yang, Jin, Schneller, Chripa ve Roche, Stephen. 2015. The Role of Higher Education in Promoting Lifelong Learning. UNESCO Institute for Lifelong Learning Feldbrunnenstrasse, Hamburg Germany.

Yardımcıoğlu, Fatih. 2012. "OECD Ülkelerinde Sağlık ve Ekonomik Büyüme İlişkisinin Ekonometrik Bir İncelemesi.” Eskişehir Osmangazi Üniversitesi Sosyal Bilimler Dergisi 13(2), 27-47.

$\mathrm{Yu}$, Haiqing, Zhao, Shukuan, Xu, Xiaobo ve Wang, Yilin. 2014. "An Empirical Study on the Dynamic Relationship between Higher Educational Investment and Economic Growth using VAR Model." Systems Research and Behavioral Science 31: 461-470.

Zhao, Xuelian, Zou, Yu, Yin, Jiuli ve Fan, Xinghua. 2017. "Cointegration Relationship between Carbon Price and Its Factors: Evidence from Structural Breaks Analysis.” Energy Procedia 142: 2503-2510. 
Dursun, G., Yeşilmen, Z. / Journal of Yasar University, 2021, 16/61, 434-454

Zivot, Eric ve Andrews, Donald W.K. 1992. "Further Evidence on the Great Crash, the Oil-Price Shock, and the Unit-Root Hypothesis.” Journal of Business \& Economic Statistics 10(3), 251-270. 